\title{
PENGARUH BIAYA PEMASARAN DAN AVERAGE COLLACTION PERIOD TERHADAP PERJUALAN STABILIZER DI CV AGUNG JAYA
}

\author{
Enika Diana Batubara, SE,M.Si \\ Universitas Amir Hamzah \\ enika_diana@yahoo.com
}

\begin{abstract}
Abstrak
Penjualan merupakan proses dimana pembeli dan penjual mendapatkan kebutuhan yang mereka inginkan melalui pertukaran informasi dan kepentingan. Penjualan secara kredit memiliki keunggulan dalam meningkatkan penjualan di perusahaan dikarenakan pada umumnya konsumen lebih tertarik membeli produk tersebut apabila perusahaan memberikan fasilitas penjualan secara kredit kepada konsumen. Akan tetapi penjualan secara kredit memiliki resiko yang tinggi dikarenakan adanya kemungkinan piutang usaha yang tidak akan tertagih. Perusahaan sebelum memutuskan melakukan penjualan kredit, maka hal yang harus diperhatikan adalah memperhitungkan mengenai jumlah dana yang diinvestasikan dalam piutang, syarat penjualan dan pembayaran yang diinginkan, kemungkinan kerugian piutang (piutang tak tertagih), biaya-biaya yang akan timbul dalam menangani piutang dan kemampuan konsumen dalam melunasi hutang tersebut dalam jangka waktu yang telah ditetapkan.
\end{abstract}

Keyword : Biaya Pemasaran, Average Collaction Period, Penjualan.

\section{PENDAHULUAN}

Penjualan merupakan proses dimana pembeli dan penjual mendapatkan kebutuhan yang mereka inginkan melalui pertukaran informasi dan kepentingan. Pada umumnya tujuan suatu perusahaan ditinjau dari sudut pandang ekonomi adalah untuk memperoleh keuntungan (profit oriented) dan menjaga kelangsungan hidup operasi perusahaan, sehingga mampu berkembang menjadi perusahaan yang besar dan tangguh. Pengaruh era globalisasi dan informasi saat ini sangat berpengaruh terhadap perusahaan, dimana tingkat persaingan antar perusahaan sangat tinggi sehingga perusahaan melakukan berbagai cara antara lain dengan memberikan

Jurnal Insitusi Politeknik Ganesha Medan 
kemudahan dalam pengurusannya, tindakan promosi yang sering dilakukan, menciptakan berbagai produk dengan berbagai inovasi dan menjualnya kepada konsumen. Perusahaan melakukan pemasaran agar produk tersebut dapat dikenal dan dibeli oleh konsumen, baik pemasaran melalui media cetak, internet maupun melalui periklanan. Perusahaan juga harus menggunakan serangkaian alat penjualan dan promosi yang efektif guna merangsang pembelian dalam jumlah yang lebih banyak dan memberikan kemudahan kepada konsumen yaitu berupa fasilitas penjualan secara kredit. Penjualan didalam suatu perusahaan terdiri dari 2 macam yaitu penjualan secara tunai dimana perusahaan akan langsung memperoleh kas tanpa adanya resiko apapun karena langsung menerima kas dari konsumen dan penjualan secara kredit dimana perusahaan tidak langsung menerima kas tersebut, tetapi menimbulkan piutang kepada konsumen yang disebut piutang usaha, dan memiliki jatuh tempo sesuai prosedur perusahaan dimana saat sudah jatuh tempo piutang tersebut berubah menjadi kas.

\section{KAJIAN PUSTAKA}

Average collection period (hari rata-rata pengumpulan piutang) digunakan untuk mengukur periode rata-rata yang diperlukan untuk mengumpulkan piutang (dalam satuan hari) setelah melakukan penjualan secara kredit. Apabila semakin meningkat Average Collection Period dari waktu ke waktu, maka tidak memenuhi syarat pembayaran yang telah ditetapkan dalam penjualan kredit, sehingga perusahaan akan berpikir kembali untuk memberikan penjualan kredit kepada konsumen dan akhirnya penjualan juga akan ikut menurun. Menurut Kasmir (2012;178) average collection period adalah rata-rata hari yang diperlukan untuk mengubah piutang menjadi kas. Fenomena penjualan pada perusahaan CV Agung Jaya mengalami variasi angka yang berbeda-beda, diindikasikan disebabkan oleh berbagai variasi angka biaya pemasaran dan average collection period.

Biaya Pemasaran adalah Biaya-biaya yang diperlukan untuk memasarkan, mendistribusikan dan melayani produk atau jasa. Indikator biaya pemasaran adalah beban pemasaran yang terdiri dari biaya iklan, gaji karyawan bagian advertensi, biaya pameran, biaya promosi, biaya contoh. Skala ukur biaya pemasaran adalah rasio.

Penjualan adalah sebuah proses dimana kebutuhan pembeli dan kebutuhan penjual dipenuhi, melalui antar pertukaran informasi dan kepentingan. Indikator penjualan adalah mencapai penjualan, mendapatkan laba, menunjang pertumbuhan perusahaan. Skala ukur penjualan adalah rasio.

Jurnal Insitusi Politeknik Ganesha Medan 


\section{Lokasi Penelitian}

\section{METODE PENELITIAN}

Lokasi penelitian ini dilakukan di CV Agung Jaya yang beralamat di Jalan Purwosari No 25C, Medan.

\section{Populasi dan Sampel}

Populasi dan sampel dalam penelitian ini adalah data biaya pemasaran, data average collection period dan data penjualan CV Agung Jaya periode Januari 2017 sampai Desember 2020 sebanyak 48 laporan.

Sampel diambil dengan menggunakan metode sampel jenuh. Data yang digunakan dalam penelitian ini berupa data sekunder.

\section{Analisis Linear Berganda}

Menurut Sujarweni $(2015 ; 227)$ penelitian ini bertujuan untuk melihat pengaruh antara variabel independen dan variabel dependen dengan skala pengukuran atau rasio dalam suatu persamaan linier, dalam penelitian ini digunakan analisis regresi berganda yang diolah dengan perangkat lunak Statistical Product and Service Solutions (SPSS) versi 17.

Model persamaan regresi berganda adalah :

$\mathbf{Y}=\alpha+\beta_{1} \mathbf{X}_{1}+\beta_{2} \mathbf{X}_{2}+\mathbf{e}$

Keterangan :

Y : Penjualan

$\mathrm{X}_{1} \quad$ : Biaya pemasaran

$\mathrm{X}_{2}$ : Average Collection Period)

$\alpha \quad$ : Konstanta

$\beta_{1} \beta_{2}$ : Koefisien regresi

e :Error 


\section{DISCUSSION}

\section{Pengujian Asumsi Klasik}

\section{Hasil Uji Normalitas}

Histogram

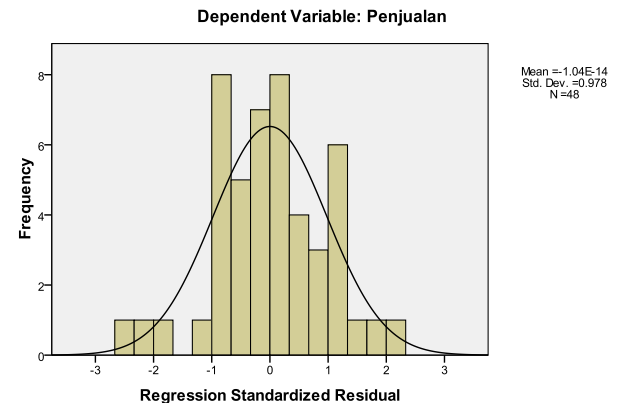

Sumber : Data diolah, 2021 (hasil output SPSS)

Berdasarkan gambar diatas, maka dapat dijelaskan bahwa data membentuk garis kurva cenderung simetri terhadap mean (U). Hasil pengujian ini menunjukkan bahwa data berdistribusi normal

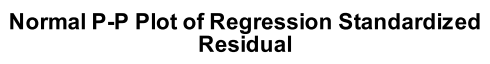

Dependent Variable: Penjualan

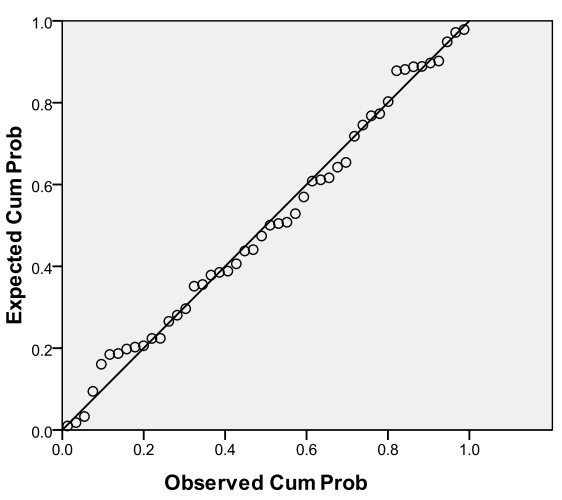

Sumber : Data diolah, 2021 (hasil output SPSS)

Berdasarkan gambar diatas, maka dapat dijelaskan bahwa data menyebar mengikuti garis diagonal. Hasil pengujian ini menunjukkan bahwa data berdistribusi normal. 


\section{One-Sample Kolmogorov-Smirnov}

\begin{tabular}{lcr}
\multicolumn{2}{c}{ Test } \\
\hline & & $\begin{array}{r}\text { Unstandardi } \\
\text { zed Residual }\end{array}$ \\
\hline $\mathrm{N}$ & Mean & .0000000 \\
Normal & Std. Deviation & .22464501 \\
Parameters ${ }^{a, b}$ & Absolute & .075 \\
Most Extreme & Positive & .055 \\
Differences & Negative & -.075 \\
& .521 \\
Kolmogorov-Smirnov Z & .949 \\
Asymp. Sig. (2-tailed) & \\
\hline a. Test distribution is Normal. & \\
b. Calculated from data. &
\end{tabular}

Sumber : Data diolah, 2021 (hasil output SPSS)

Berdasarkan tabel diatas, maka dapat diketahui nilai signifikan lebih besar dari 0.05, yaitu sebesar 0.949. Hasil pengujian ini menunjukkan bahwa data berdistribusi normal.

\section{Hasil Uji Heteroskedastisitas}

Scatterplot

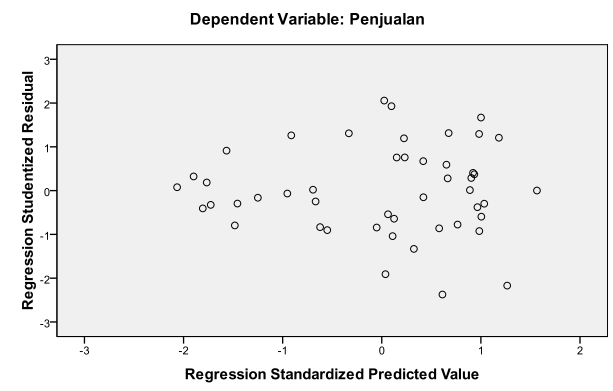

Sumber : Data diolah, 2021 (hasil output SPSS)

Berdasarkan gambar diatas, maka dapat dijelaskan bahwa titik-titik hasil pengolahan data menyebar dibawah maupun diatas titik origin (angka 0) pada sumbu Y dan tidak mempunyai pola yang teratur. Hasil pengujian ini menunjukkan bahwa tidak terjadi heteroskedastisitas atau terjadi homoskedastisitas. 


\section{Hasil Uji Autokorelasi}

\begin{tabular}{|c|c|c|c|c|c|}
\hline \multicolumn{6}{|c|}{ Model Summary ${ }^{\mathrm{b}}$} \\
\hline $\begin{array}{l}\text { Mod } \\
\text { el }\end{array}$ & $\mathrm{R}$ & $\begin{array}{c}\mathrm{R} \\
\text { Square }\end{array}$ & $\begin{array}{l}\text { Adjusted } \\
\mathrm{R} \text { Square }\end{array}$ & $\begin{array}{l}\text { Std. Error } \\
\text { of the } \\
\text { Estimate }\end{array}$ & $\begin{array}{l}\text { Durbin- } \\
\text { Watson }\end{array}$ \\
\hline 1 & $.366^{\mathrm{a}}$ & .134 & .096 & .22958 & 1.976 \\
\hline
\end{tabular}

Sumber : Data diolah, 2021 (hasil output SPSS)

Berdasarkan tabel diatas, maka dapat diketahui nilai Durbin-Watson (d) adalah sebesar 1.976. Nilai tersebut akan dibandingkan dengan nilai tabel Durbin-Watson yang menggunakan signifikansi 5\% untuk jumlah sampel (n) sebanyak 48 dan jumlah variabel independen $(\mathrm{k})$ sebanyak 2. Berdasarkan tabel Durbin-Watson, dapat diketahui nilai dL sebesar 1.4500 dan nilai dU sebesar 1.6231. Oleh karena itu, nilai d, dL, dU tersebut memenuhi kriteria ke-V dengan syarat $\mathrm{dU}<\mathrm{d}<4-\mathrm{dU}(1.6231<1.976<4-1.6231)$, yaitu dengan nilai $1.6231<$ $1.976<2.3769$. Hasil pengujian ini menunjukkan bahwa tidak ada korelasi positif atau negative.

\section{Hasil Uji Multikolinearitas}

\begin{tabular}{|c|c|c|c|}
\hline \multicolumn{4}{|c|}{ Coefficients $^{\mathbf{a}}$} \\
\hline & & \multicolumn{2}{|c|}{$\begin{array}{l}\text { Collinearity } \\
\text { Statistics }\end{array}$} \\
\hline \multicolumn{2}{|c|}{ Model } & Tolerance & VIF \\
\hline \multirow[t]{3}{*}{1} & (Constant) & & \\
\hline & Biaya Pemasaran & .992 & 1.008 \\
\hline & $\begin{array}{l}\text { Average Collection } \\
\text { Period }\end{array}$ & .992 & 1.008 \\
\hline
\end{tabular}

Sumber : Data diolah, 2021 (hasil output SPSS)

Berdasarkan tabel diatas, maka dapat diketahui bahwa :

1. Nilai tolerance $(\alpha)$ untuk variabel biaya pemasaran dan average collection period memiliki nilai lebih besar dari 0.1, yaitu sebesar 0.992 .

2. Nilai variance inflation factor (VIF) untuk biaya pemasaran dan average collection period memiliki nilai lebih kecil dari 10, yaitu sebesar 1.008.

Hasil pengujian diatas menunjukkan bahwa variabel independen (biaya pemasaran dan average collection period) tidak mengalami multikolinearitas. 


\section{Hasil Analisis Regresi Linier}

\begin{tabular}{|c|c|c|c|c|c|}
\hline \multicolumn{6}{|c|}{ Coefficients $^{\mathrm{a}}$} \\
\hline \multirow[b]{2}{*}{ Model } & $\begin{array}{r}\text { Unstan } \\
e c \\
\text { Coeffi }\end{array}$ & $\begin{array}{l}\text { dardiz } \\
\text { cients }\end{array}$ & $\begin{array}{c}\text { Standardi } \\
\text { zed } \\
\text { Coefficie } \\
\text { nts }\end{array}$ & & \\
\hline & B & $\begin{array}{c}\text { Std. } \\
\text { Error }\end{array}$ & Beta & $\mathrm{t}$ & Sig. \\
\hline 1 (Constant) & 12.270 & 2.876 & & 4.266 & .000 \\
\hline $\begin{array}{l}\text { Biaya } \\
\text { Pemasaran }\end{array}$ & .095 & .090 & .148 & 1.064 & .293 \\
\hline $\begin{array}{l}\text { Average } \\
\text { Collection } \\
\text { Period }\end{array}$ & 1.068 & .461 & .322 & 2.315 & .025 \\
\hline
\end{tabular}

Sumber : Data diolah, 2021 (hasil output SPSS)

Berdasarkan tabel diatas, maka dapat diketahui persamaan regresi berganda dalam penelitian ini adalah :

Penjualan $=12.270+0.095$ Biaya Pemasaran +1.068 Average Collection Period + e.

\section{Hasil Uji Koefisien Determinasi $\left(\mathbf{U j i} \mathbf{R}^{2}\right)$}

\begin{tabular}{|c|c|c|c|c|c|}
\hline \multicolumn{6}{|c|}{ Model Summary } \\
\hline $\begin{array}{l}\text { Mod } \\
\text { el }\end{array}$ & $\mathrm{R}$ & $\begin{array}{c}\mathrm{R} \\
\text { Square }\end{array}$ & $\begin{array}{l}\text { Adjusted } \\
\text { R Square }\end{array}$ & $\begin{array}{l}\text { Std. Error } \\
\text { of the } \\
\text { Estimate }\end{array}$ & $\begin{array}{l}\text { Durbin- } \\
\text { Watson }\end{array}$ \\
\hline 1 & $.366^{\mathrm{a}}$ & .134 & .096 & .22958 & 1.976 \\
\hline \multicolumn{6}{|c|}{$\begin{array}{l}\text { a. Predictors: (Constant), Average Collection Period, } \\
\text { Biaya Pemasaran }\end{array}$} \\
\hline \multicolumn{6}{|c|}{ b. Dependent Variable: Penjualan } \\
\hline
\end{tabular}

Sumber : Data diolah, 2021 (hasil output SPSS)

Berdasarkan tabel diatas, maka dapat diketahui nilai R Square adalah sebesar 0.134 atau $13.4 \%$. Hal ini berarti sebesar $13.4 \%$ variabel penjualan dapat dijelaskan oleh variabel biaya pemasaran dan average collection period, sedangkan sisanya sebesar $86.6 \%$ variabel penjualan dapat dijelaskan oleh variabel lain yang tidak diteliti dalam penelitian ini. 


\section{Hasil Uji Signifikansi Parsial (Uji t)}

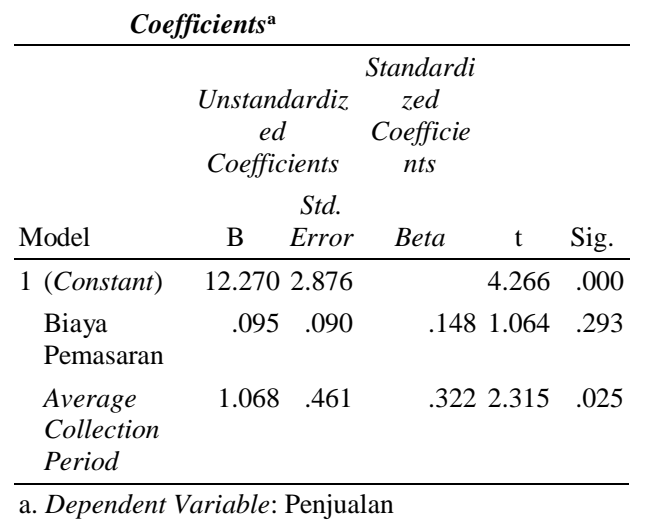

Sumber : Data diolah, 2021 (hasil output SPSS)

\section{KESIMPULAN}

Berdasarkan hasil analisis dan pembahasan yang telah diuraikan, maka kesimpulan dalam penelitian ini adalah :

1. Persamaan regresi linier berganda dalam penelitian ini adalah Penjualan $=$ 12.270 + 0.095 Biaya Pemasaran + 1.068 Average Collection Period + e.

2. Secara parsial, variabel biaya pemasaran tidak berpengaruh tidak signifikan terhadap penjualan pada perusahaan CV Agung Jaya periode Januari 2017 - Desember 2020 dengan nilai $t_{\text {hitung }}<t_{\text {tabel }}$ yaitu $1.064<$ 2.01410 dan nilai signifikan $>0.05$ yaitu $0.293>0.05$.

3. Secara parsial, variabel average collection period berpengaruh signifikan terhadap penjualan pada perusahaan CV Agung Jaya periode Januari 2017

- Desember 2020 dengan nilai $t_{\text {hitung }}>\mathrm{t}_{\text {tabel }}$ yaitu $2.315>2.01410$ dan nilai signifikan $<0.05$ yaitu $0.025<0.05$.

4. Secara simultan, variabel biaya pemasaran dan average collection period berpengaruh signifikan terhadap penjualan pada perusahaan CV Agung Jaya periode Januari 2017 - Desember 2020 dengan nilai $F_{\text {hitung }}>F_{\text {tabel }}$ yaitu $3.491>2.81$ dan nilai signifikan $<0.05$ yaitu $0.039<0.05$.

5. Besarnya pengaruh yang diberikan oleh variabel biaya pemasaran dan average collection period terhadap penjualan adalah sebesar $13.4 \%$, sedangkan sisanya sebesar $86.6 \%$ dapat dijelaskan oleh variabel lain seperti biaya produksi, biaya distribusi, biaya promosi, gaji karyawan.

Jurnal Insitusi Politeknik Ganesha Medan 


\section{REFERENCES}

Ghozali, Imam. 2011. Aplikasi Analisis Multivariate Dengan Program SPSS. Semarang : Badan Penerbit Universitas Diponegoro. 2013. Aplikasi Analisis Multivariate dengan Program IBM SPSS21. Semarang : Badan Penerbit Universitas Diponegoro.

Kasmir. 2012. Analisis Laporan Keuangan. Jakarta : PT. Raja Garfindo Persada.

Sujarweni, Wiratna. 2015. SPSS Untuk Penelitian. Yogyakarta : Pustaka Baru Press.

Sunyoto, Danang. 2013. Metodologi Penelitian Akuntansi. Bandung : PT. Refika Aditama.

Tungga, Ananta Wikrama, Komang Adi Kurniawan Saputra dan Diota

Prameswari Vijaya. 2014. Metode Penelitian Bisnis. Yogyakarta : Graha Ilmu. www.junaidichaniago.wordpress.com 